\title{
Hydrogen Sulfide Decreases Blood-Brain Barrier Damage via Regulating Protein Kinase $C$ and Tight Junction After Cardiac Arrest in Rats
}

\author{
Hangbing $\mathrm{Li}^{\mathrm{a}} \quad \mathrm{Lin} \mathrm{Zhu}^{\mathrm{b}} \quad$ Jingwei Feng ${ }^{\mathrm{b}}$ Xiaotong Hub Chen $\mathrm{Li}^{\mathrm{b}}$ \\ Bing Zhang ${ }^{b}$ \\ aDepartment of Anesthesiology, First Affiliated Hospital of Harbin Medical University, Harbin, \\ ${ }^{b}$ Department of Anesthesiology, Second Affiliated Hospital of Harbin Medical University, Harbin, China
}

\section{Key Words}

Blood-brain barrier $\cdot$ Cardiac arrest $\bullet$ Hydrogen sulfide $\cdot$ Protein kinase $C \cdot$ Tight junction

\begin{abstract}
Background/Aims: Hydrogen sulfide $\left(\mathrm{H}_{2} \mathrm{~S}\right)$ can decrease blood-brain barrier (BBB) permeability after cardiac arrest (CA) and resuscitation; however, the underlying mechanisms are not understood clearly. Methods: We investigated the effects of inhalation of $\mathrm{H}_{2} \mathrm{~S}$ on $\mathrm{CA}$ and resuscitation in a rat model of CA. We used Evans blue to detect the integrity of BBB and Western blot to assess the activation of protein kinase $c$ (PKC) isozymes and the expression of Claudin-5, Occludin, and ZO-1. Neurological deficit scales and the 14-days survival rate were measured. Results: We determined that inhalation of 40 p.p.m or 80 p.p.m $\mathrm{H}_{2} \mathrm{~S}$ significantly decreased brain water content and Evans blue leakage, ameliorated neurologic deficit scale and improved 14-days survival rate. $\mathrm{H}_{2} \mathrm{~S}$ inhibited the activation of PKC- $\alpha, \beta$ I, $\beta$ II and $\delta$, impelled the activation of $\mathrm{PKC}-\varepsilon$, and increased the expression of Claudin-5, Occludin and ZO-1. Conclusions: $\mathrm{H}_{2} \mathrm{~S}$ improved the integrity of $\mathrm{BBB}$, mitigated brain edema; improved neurological outcome and 14-days survival rate in rats after CA and resuscitation. The beneficial effects of $\mathrm{H}_{2} \mathrm{~S}$ may be associated with inhibiting the activation of PKC- $\alpha, \beta$ I, $\beta$ II and $\delta$, promoting the activation of $\mathrm{PKC}-\varepsilon$, and increasing the expression of Claudin-5, Occludin and ZO-1.

(C) 2018 The Author(s)

Published by S. Karger AG, Basel
\end{abstract}

\section{Introduction}

Cardiac arrest (CA) is a leading cause of death in America [1]. Even with effective primary cardiopulmonary resuscitation measures, only about 30\% CA patients survive while most of them suffer from severe post-CA neurological defects due to cerebral injury [2]. Blood-brain 
barrier (BBB) plays an important role in the process of cerebral ischemia-reperfusion (I/R) injury induced by CA and resuscitation [3]. Therefore, efficacious therapies that target in decreasing cerebral injury will rely on methods that can preserve or recover the integrity of BBB.

Protein kinase $\mathrm{C}(\mathrm{PKC})$ represents a family of serine/threonine protein kinases which is integral to the structure and function of BBB [4-8]. The PKC family consists of 12 isozymes [9], among which 10 are expressed in brain microvascular endothelial cells and participate in a multitude of physiological functions including gene expression, cell proliferation and differentiation, and intracellular signal transduction pathways [10]. Previously, a study determined that I/R activated PKCs by enabling their translocation from the cytosol to cytomembrane [11]. In turn, the activated and translocated PKCs can phosphorylate the serine/threonine sites of relevant proteins, including tight junction (TJ) proteins which maintain the integrity of BBB [4]. PKCs, especially PKC- $\alpha$, PKC- $\beta$, and PKC- $\delta$, directly or indirectly act on TJ proteins such as ZO-1, Claudin-5, and Occludin, thereafter attenuating their expression [5-7]. However, another study had shown that PKC- $\eta$ plays a vital role in the assembly and maintenance of TJ proteins [8].

Hydrogen sulfide $\left(\mathrm{H}_{2} \mathrm{~S}\right)$ has been reported as another gas, besides carbon monoxide and nitric oxide, with signal transduction modulatory capacity [12]. Many studies have shown that $\mathrm{H}_{2} \mathrm{~S}$ has the potential effects on decreasing oxidative stress damage, inhibiting cell apoptosis, regulating NMDA receptors, attenuating neurologic deficits, and promoting nerve functional recovery $[13,14]$, which were consistent with the results obtained in our previous studies [15]. Beyond these findings, inhalation of $\mathrm{H}_{2} \mathrm{~S}$ attenuates BBB permeability and brain edema in CA and resuscitation rats [16]. In addition, $\mathrm{H}_{2} \mathrm{~S}$ may potentially regulate the activity of PKC isoforms, especially PKC- $\alpha$ and PKC- $\varepsilon$ [17]. However, the effects of $\mathrm{H}_{2} \mathrm{~S}$ on $\mathrm{PKC}$ isozymes and TJ proteins after CA and resuscitation remain unknown.

In this study, we investigated the effects of exogenous $\mathrm{H}_{2} \mathrm{~S}$ on the integrity of BBB; and further, we investigated whether these effects were associated with PKC and TJ in rats undergoing $\mathrm{CA}$ and resuscitation.

\section{Materials and Methods}

\section{Animals}

All experimental procedures were approved by the Institutional Animal Care and Use Committee of Harbin Medical University (Heilongjiang, China). Male Sprague-Dawley rats weighing 280 - $300 \mathrm{~g}$ (Beijing Vital River Laboratory Animal Technology Co., Ltd., Beijing, China) were housed under $12 \mathrm{~h}$ light/12 h dark cycles with food and water available ad libitum. Animals were used and treated in a non-stressful environment according to the guidelines of the Laboratory Animal Center of Harbin Medical University in this study. All studies involving animals are reported in accordance with the ARRIVE guidelines for reporting experiments involving animals $[18,19]$.

\section{Cardiac arrest and resuscitation model}

All rats were fasted except for free access to water before the experiment. Rats were anesthetized with 3-5\% isoflurane mixed with 30\% oxygen and 70\% nitrogen as described previously with some minor modifications [20]. Rats were mechanically ventilated (InspiraASV, Harvard Apparatus, USA) with a frequency of $50-60$ breaths/min and a tidal volume of $10 \mathrm{ml} / \mathrm{kg}$ after endotracheal intubation and the parameters were adjusted accordingly to maintain the arterial blood gas at $\mathrm{pH} 7.35-7.45, \mathrm{PaCO}_{2}$ 35-45 mmHg and $\mathrm{PaO}_{2} \geq 90 \mathrm{mmHg}$. A standard lead II electrocardiography was recorded continuously by subdermal electrodes and rectal temperature was monitored using a thermometer probe and maintained at $37 \pm 0.5^{\circ} \mathrm{C}$ with the MP150 biological signals and data acquisition system (BIOPAC Systems, Inc., Goleta, CA, USA). Two 18-gauge catheters were inserted into the left femoral vein and the caudal ventral artery for drug and fluid administration and continuous arterial blood pressure monitoring respectively.

Cardiac arrest was induced by ventricular fibrillation as previously described [20]. Ventricular fibrillation was induced using an esophageal electrode (5F, Bard Peripheral Vascular, Tempe, AZ, USA) with 
a 1-minute pulse of a $12 \mathrm{~V}, 50$

$\mathrm{Hz}$ alternating current. In case of spontaneous defibrillation, additional 20 seconds impulses were delivered [20]. CA was confirmed by an abrupt decrease in mean arterial pressure to < $15 \mathrm{mmHg}$.

After 6 minutes of CA, cardiopulmonary resuscitation (CPR) was performed with sternal compression at a rate of 200/minute and mechanical ventilation was resumed with $100 \%$ oxygen. A bolus of epinephrine $(0.02 \mathrm{mg} / \mathrm{kg})$ and sodium bicarbonate $(1 \mathrm{mEq} /$ $\mathrm{kg)}$ was administered. After 2 minutes of CPR, a biphasic shock

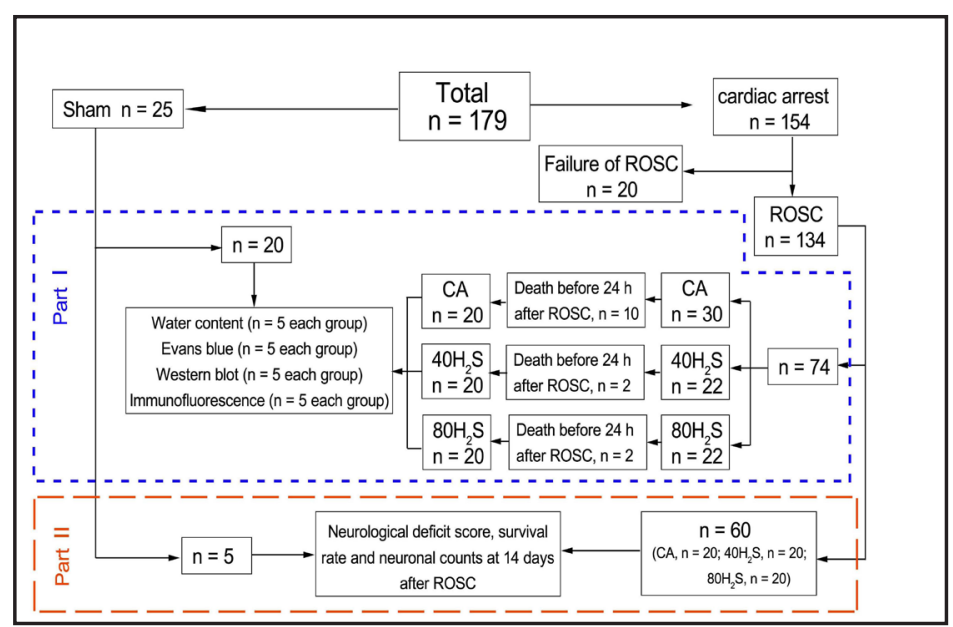

Fig. 1. Experimental flow graph. $40 \mathrm{H}_{2} \mathrm{~S}, 40 \mathrm{H}_{2} \mathrm{~S}$ group; $80 \mathrm{H}_{2} \mathrm{~S}, 80 \mathrm{H}_{2} \mathrm{~S}$ group; CA, CA / CPR resuscitation group; ROSC, return of spontaneous circulation. of 2 J (HeartStart XL M4735A

defibrillator, Philips Medical Systems, Andover, MA, USA) was performed for external defibrillation. Then the cycle of chest compressions for 1 minute followed by defibrillation were repeatedly performed until the return of spontaneous circulation (ROSC). Achievement of ROSC was defined by spontaneous cardiac rhythm in combination with a mean arterial pressure of $50 \mathrm{mmHg}$ or greater. If CPR exceeded 10 minutes without ROSC, the CPR was stopped.

After that, all the resuscitated rats were randomly divided into three groups: CA / CPR group (CA group), 40 p.p.m. $\mathrm{H}_{2} \mathrm{~S}$ group ( $40 \mathrm{H}_{2} \mathrm{~S}$ group) and 80 p.p.m. $\mathrm{H}_{2} \mathrm{~S}$ group $\left(80 \mathrm{H}_{2} \mathrm{~S}\right.$ group). Rats in CA group inhaled $30 \%$ oxygen for $1 \mathrm{~h}$, while rats in $40 \mathrm{H}_{2} \mathrm{~S}$ or $80 \mathrm{H}_{2} \mathrm{~S}$ group inhaled $30 \%$ oxygen with 40 p.p.m. or 80 p.p.m. $\mathrm{H}_{2} \mathrm{~S}$, respectively, for $1 \mathrm{~h}$. Blood gas analyses were performed and appropriate ventilator adjustments were made. Vascular catheters were removed, surgical wounds were sutured and infiltrated with $0.25 \%$ bupivacaine after $1 \mathrm{~h}$ of ROSC. Rats were then weaned from the ventilator, extubated, and placed in a chamber enriched in $50 \%$ oxygen with or without different concentrations of $\mathrm{H}_{2} \mathrm{~S}$ for another $1 \mathrm{~h}$. Rats in Sham group were anesthetized and operated surgically as aforementioned without ventricular fibrillation.

The whole experiment consisted of two parts. In Part I, we examined brain water content, Evans blue leakage, and performed western blot analysis and immunofluorescence after $24 \mathrm{~h}$ of ROSC. In Part II, we recorded neuronal deficit score was detected at $24 \mathrm{~h}$ and 14 days after ROSC; we also evaluated the survival rate during the 14 days after ROSC. For experimental details, see Fig. 1.

\section{Assessment of brain water content}

Brain tissue was immediately dissected, weighed, and designated as the wet weight. The tissues were then placed in an oven $\left(105^{\circ} \mathrm{C}\right)$ and dried for $72 \mathrm{~h}$ to obtain the dry weight. The brain water content was calculated by the formula: ([wet weight - dry weight]/ wet weight) $\times 100 \%$ [21] .

\section{Evans blue leakage}

Two percent Evans blue (EB; Sigma, MO, USA) dissolved in saline was administered intravenously and circulated for 30 minutes. Then, rats were transcardially perfused with saline to remove residual EB from circulation. Brain tissues were rinsed with PBS followed by sectioning two 4 mm-wide slices from $1.8 \mathrm{~mm}$ anterior to the bregma to $6.2 \mathrm{~mm}$ posterior to the bregma. The cerebral cortex above the rhinal fissure was dissected from the two slices, respectively. Thereafter, cortex was homogenized in $50 \%$ trichloroacetic acid, and the samples were centrifuged at 21, $000 \mathrm{~g}$ for $30 \mathrm{~min}$. The concentration of EB extracted in the supernatant was analyzed spectrophotometrically at $620 \mathrm{~nm}$ against a standard curve. The standard curve was constructed using dilution of Evans blue dye in a range from 3 to $400 \mathrm{ng} / \mathrm{ml}$ [15]. 


\section{Cellular Physiology Cell Physiol Biochem 2018;47:994-1006 and Biochemistry Publisned onIIne: IVlay 30, $2018 \quad \begin{aligned} & \text { DOI: 10.1159/000490166 } 2018 \text { The Author(s). Published by S. Karger AG, Basel } \\ & \text { www.karger.com/cpb }\end{aligned}$}

Li et al.: $\mathrm{H}_{2} \mathrm{~S}$ Decreases BBB Damage via Regulating PKC and TJ in CA

\section{Cerebral microvessel isolation}

The brain microvessels were isolated as previously described with minor adjustments [22]. In brief, cerebral tissue of prefrontal cortex was homogenized in microvessel isolation buffer $(\mathrm{pH}=7.4)$ containing $103 \mathrm{mM} \mathrm{NaCl}, 2.5 \mathrm{mM} \mathrm{CaCl}_{2}, 4.7 \mathrm{mM} \mathrm{KCl}, 1.2 \mathrm{mM} \mathrm{KH}_{2} \mathrm{PO}_{4}, 1.2 \mathrm{mM} \mathrm{MgSO}_{4}, 2.5 \mathrm{mM} \mathrm{NaHCO}{ }_{3}, 15 \mathrm{mM}$ HEPES, $10 \mathrm{mM}$ glucose, $1 \mathrm{mM}$ sodium pyruvate, and $10 \mathrm{~g} / \mathrm{L}$ dextran (MW 64, 000) with protease inhibitor (PMSF, Beyotime Institute of Biotechnology, Jiangsu, China). Ice-cold dextran was added to the homogenate, oscillated, and centrifuged at 5, $600 \mathrm{~g}$ for $10 \mathrm{~min}$ at $4^{\circ} \mathrm{C}$. The pellets were resuspended in microvessel isolation buffer, and passed through a $70 \mu \mathrm{m}$ filter (Becton Dickinson, Franklin Lakes, NJ). The filtrate was centrifuged at $3,000 \mathrm{~g}$ in isolation buffer at $4^{\circ} \mathrm{C}$ and the pellet consisting of microvessels was collected.

\section{Measurement of proteins level}

RIPA lysis buffer was added into the precipitate containing microvessels. After incubation on ice, the mixture was centrifuged at $16,000 \mathrm{~g}$ for $20 \mathrm{~min}$ at $4^{\circ} \mathrm{C}$ and the supernatant was collected for detection of TJ proteins. In order to measure the translocation of PKC isozymes, proteins of cytoplasm and membrane were extracted respectively as previously described [20]. Another precipitate containing microvessels was resuspended in ice-cold lysis buffer containing $125 \mathrm{mM} \mathrm{NaCl}, 5 \mathrm{mM}$ EDTA, 1\% Nonidet P-40, $25 \mathrm{mM}$ Tris $(\mathrm{pH} 7.5)$ and protease inhibitors and shaken on ice for $1 \mathrm{~h}$. The lysate was centrifuged at $500 \mathrm{~g}$ for $10 \mathrm{~min}$ at $4^{\circ} \mathrm{C}$ to discard the pellet rich of nuclei. After that, supernatant was centrifuged again at $20,000 \mathrm{~g}$ at $4^{\circ} \mathrm{C}$ for $20 \mathrm{~min}$. The supernatant was collected as cytosolic fraction. The pellet was resuspended in lysis buffer containing 1\% Triton X-100 and incubated on ice for another $1 \mathrm{~h}$. Then, the hybrid was centrifuged at 20, $000 \mathrm{~g}$ at $4^{\circ} \mathrm{C}$ for $20 \mathrm{~min}$ and the supernatant was collected as membrane fraction.

Equal amounts of the protein samples were separated by $10 \%$ sodium dodecyl sulphate-polyacrylamide gel on Mini-PROTEAN Tetra Cell System (Bio-Rad, Hercules, CA) and then transferred onto polyvinylidene difluoride (PVDF) membranes. Then, membranes were blocked in 5\% skim milk (Difco, Solarbio, Beijing, China) and then incubated with various primary antibodies against ZO-1 (1:250; Invitrogen, Thermo Fisher Scientific, MA, USA), Occludin (1:1000; Abcam, Cambridge, UK), PKC- $\beta$ I (1:1000; Abcam), PKC- $\beta$ II (1:1000; Abcam), Claudin-5 (1:250; Bioss Biosynthesis Biotechnology, Beijing, China), PKC- $\alpha$ (1:1250; Santa Cruz Biotechnology, CA, USA), PKC- $\delta$ (1:500; SCBT) and PKC- $\varepsilon\left(1: 500\right.$; SCBT) at $4^{\circ} \mathrm{C}$ overnight. The membranes were incubated with horseradish peroxidase-linked anti-rabbit IgG (1:5000; ZSGB-BIO, Beijing, China) or anti-mouse IgG (1:5000; ZSGB-BIO) at $25^{\circ} \mathrm{C}$ for 1 hour after three washes in TBST buffer and then again washed three times in TBST buffer. The ECL $\AA$ kit (GE healthcare, UK) was used for image development and the density of the bands was quantified by ImageJ software (NIH).

\section{Evaluation of neurological function and overall survival rate}

The general neurological performance was assessed by one investigator who was blinded to the groups in all animals using the neurological deficit scale (NDS), which was established in rats undergoing CA previously [23] at $24 \mathrm{~h}$ after ROSC in each group. The score ranges from 80 points indicating a functionally normal to 0 representing brain or cardiac death. Survival rate was evaluated during the 14 days after ROSC.

\section{Neuronal Counts}

The neuronal survival analysis in hippocampal CA1 region was investigated by an observer who was blinded to the experimental protocol after 14 days of ROSC. Rats were deeply anesthetized with isoflurane, perfused through the heart with $200 \mathrm{~mL} 0.1 \mathrm{~mol} / \mathrm{L}$ phosphate-buffered saline and $4 \%$ paraformaldehyde. Hippocampi were removed quickly and fixed in $4 \%$ paraformaldehyde before paraffin embedding. Hematoxylin and eosin-stained sections of the hippocampus (corresponding to bregma $-3.3 \mathrm{~cm}$ according to the atlas of Paxinos and Watson [24]) were examined. Viable neurons were defined as cells showing a distinct nucleus and nucleolus, while ischemic neurons were recognized by the pyknotic or karyorrhectic nuclei lacking a clear nucleolus. One observer, who was blinded to the experimental protocol, counted the numbers of normal-appearing pyramidal neurons per high-power field $(\times 400)$. The number of neurons in the CA1 region of hippocampus was quantitated as the mean number from five sections per rat. In each section, the number of neurons was averaged from three random different vision fields in the CA1 region under microscope $(\times 400)[25]$.

\section{Statistical analysis}

Data from the neurological deficit score was presented as the median, 25th, and 75th percentiles and statistical significance was assessed with the Kruskal-Wallis test, followed by post-hoc Mann-Whitney U 
Li et al.: $\mathrm{H}_{2} \mathrm{~S}$ Decreases BBB Damage via Regulating PKC and $\mathrm{TJ}$ in $\mathrm{CA}$

tests, when the overall Kruskal-Wallis result was significant. Other data were presented as the mean \pm SD and analyzed using ANOVA, followed by Bonferroni correction for the comparison between multiple groups. Kaplan-Meier survival curves were compared using log rank test. A $P$ value less than 0.05 was considered statistically significant. Statistical analysis was performed using SPSS® software (SPSS Inc., Chicago, IL).

\section{Results}

Hydrogen sulfide attenuates brain edema after cardiac arrest and resuscitation

As shown in Fig. 2, the brain water content was $83.7 \pm 1.0 \%$ at $24 \mathrm{~h}$ after ROSC in CA group, which was a significant increase compared with Sham group $(78.1 \pm 0.7 \%, P<0.05)$. However, there was no significant difference in $40 \mathrm{H}_{2} \mathrm{~S}$ group and $80 \mathrm{H}_{2} \mathrm{~S}$ group when compared with the Sham group. In addition, The CA-mediated increase of brain water content was significantly inhibited in $40 \mathrm{H}_{2} \mathrm{~S}$ group $(79.2 \pm 0.8 \%, P<0.05)$ and $80 \mathrm{H}_{2} \mathrm{~S}$ group $(78.6 \pm 0.7 \%$, $P<0.05$ ) indicating that inhalation of 40 p.p.m. $\mathrm{H}_{2} \mathrm{~S}$ or 80 p.p.m. $\mathrm{H}_{2} \mathrm{~S}$ decreased the brain water content after $\mathrm{CA}$ and resuscitation.

Hydrogen sulfide mitigates the damage of $B B B$ after cardiac arrest and resuscitation evaluated by Evans blue leakage

At $24 \mathrm{~h}$ after ROSC, a significant increase of EB leakage was observed in the whole brain tissue in CA group (1536 $\pm 171 \mathrm{ng} / \mathrm{g}$ ) compared with Sham group (794 $\pm 98 \mathrm{ng} / \mathrm{g}, P<0.05)$. Compared with the CA group, EB extravasation was significantly lower in $40 \mathrm{H}_{2} \mathrm{~S}$ group $(1042$ $\pm 121 \mathrm{ng} / \mathrm{g})$ and in $80 \mathrm{H}_{2} \mathrm{~S}$ group $(996 \pm 149 \mathrm{ng} / \mathrm{g})$ respectively $(P<0.05$, Fig. 3). There was no significant difference between the $40 \mathrm{H}_{2} \mathrm{~S}$ group and the $80 \mathrm{H}_{2} \mathrm{~S}$ group.

\section{Hydrogen sulfide modulates the activation of PKC isozymes}

As shown in Fig. 4, at $24 \mathrm{~h}$ after ROSC, an increased level of membrane-to-cytosol expression in PKC- $\alpha$ (Fig. 4A), $\beta$ I (Fig. 4B), $\beta$ II (Fig. 4C) and $\delta$ (Fig. 4D) was observed in CA group, but not PKC- $\varepsilon$ (Fig. 4E). The membrane-to-cytosol ratios of the PKC- $\alpha$ (1.52 \pm 0.09 fold of Sham group), $\beta$ I (1.76 \pm 0.25 -fold of Sham group), $\beta$ II (1.60 \pm 0.31 -fold of Sham group) and $\delta$ (2.04 \pm 0.23 -fold of Sham group) increased significantly, while decreased in PKC- $\varepsilon(0.63 \pm 0.11$-fold of Sham group), in CA group compared with Sham group $(P<0.05)$. This data indicated that CA and resuscitation caused an overt activation of PKC- $\alpha, \beta$ I, $\beta$ II and $\delta$, and suppressed the activation of PKC- $\varepsilon$. Compared with CA group, the membrane-tocytosol ratios of the PKC- $\alpha\left(1.13 \pm 0.06\right.$-fold of Sham group in $40 \mathrm{H}_{2} \mathrm{~S}$ group, $1.08 \pm 0.12$-fold of Sham group in $80 \mathrm{H}_{2} \mathrm{~S}$ group), $\beta$ I (1.22 \pm 0.22 -fold of Sham group in $40 \mathrm{H}_{2} \mathrm{~S}$ group, $1.15 \pm$ 0.11 -fold of Sham group in $80 \mathrm{H}_{2} \mathrm{~S}$ group), $\beta \mathrm{II}\left(0.95 \pm 0.08\right.$-fold of Sham group in $40 \mathrm{H}_{2} \mathrm{~S}$ group, $1.01 \pm 0.11$-fold of Sham group in $80 \mathrm{H}_{2} \mathrm{~S}$ group) and $\delta(1.14 \pm 0.09$-fold of Sham group in $40 \mathrm{H}_{2} \mathrm{~S}$ group, $1.02 \pm 0.10$-fold of Sham group in $80 \mathrm{H}_{2} \mathrm{~S}$ group) decreased significantly, while increased in PKC- $\varepsilon$ ( $0.91 \pm 0.09$-fold of Sham group in $40 \mathrm{H}_{2} \mathrm{~S}$ group, $0.96 \pm 0.16$-fold of Sham

Fig. 2. Brain water content of rats in Sham, $\mathrm{CA}, 40 \mathrm{H}_{2} \mathrm{~S}$ and $80 \mathrm{H}_{2} \mathrm{~S}$ groups at $24 \mathrm{~h}$ after return of spontaneous circulation ( $\mathrm{n}=5$ in each group). $40 \mathrm{H}_{2} \mathrm{~S}, \quad 40 \mathrm{H}_{2} \mathrm{~S}$ group; $80 \mathrm{H}_{2} \mathrm{~S}$, $80 \mathrm{H}_{2} \mathrm{~S}$ group; CA, CA / CPR group. ${ }^{*} \mathrm{P}<0.05$ versus Sham group. ${ }^{*} \mathrm{P}<0.05$ versus $\mathrm{CA}$ group.
Fig. 3. Bloodbrain barrier permeability evaluated using Evans blue at 24 $\mathrm{h}$ after return of spontaneous circulation ( $\mathrm{n}=5$ in each group). $40 \mathrm{H}_{2} \mathrm{~S}$, $40 \mathrm{H}_{2} \mathrm{~S}$ group;

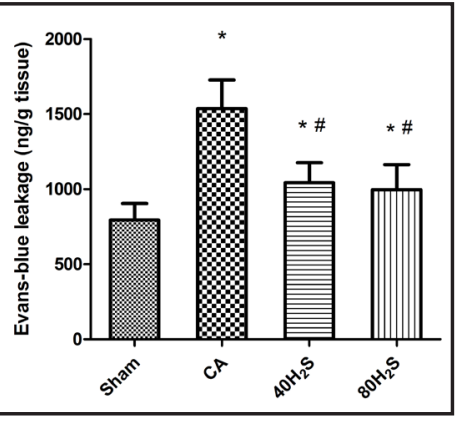
$80 \mathrm{H}_{2} \mathrm{~S}, 80 \mathrm{H}_{2} \mathrm{~S}$ group; CA, CA / CPR group. ${ }^{*} \mathrm{P}<0.05$ versus Sham group. ${ }^{\#} \mathrm{P}<0.05$ versus $C A$ group. 
Fig. 4. The activation of PKC- $\alpha(\mathrm{A})$, PKC- $\beta$ I (B), PKC- $\beta$ II (C), PKC- $\delta$ (D) and $\mathrm{PKC}-\varepsilon$ (E) in cerebral microvessels of rats in Sham, CA, $40 \mathrm{H}_{2} \mathrm{~S}$, and $80 \mathrm{H}_{2} \mathrm{~S}$ groups at 24 $\mathrm{h}$ after return of spontaneous circulation ( $\mathrm{n}=5$ in each group). Representative western blots are presented above the bar charts. Membrane-to-cytosol ratio represents the level of activation of PKC isozymes and results of each group are expressed after normalized to sham group ratio. $\beta$-actin and $G \alpha$ were used as internal controls for cytosolic and membrane fractions, respectively. $40 \mathrm{H}_{2} \mathrm{~S}, 40 \mathrm{H}_{2} \mathrm{~S}$ group; $80 \mathrm{H}_{2} \mathrm{~S}, 80 \mathrm{H}_{2} \mathrm{~S}$ group; CA, CA / CPR group. ${ }^{*} \mathrm{P}<0.05$ versus Sham group. ${ }^{*} \mathrm{P}<0.05$ versus CA group.

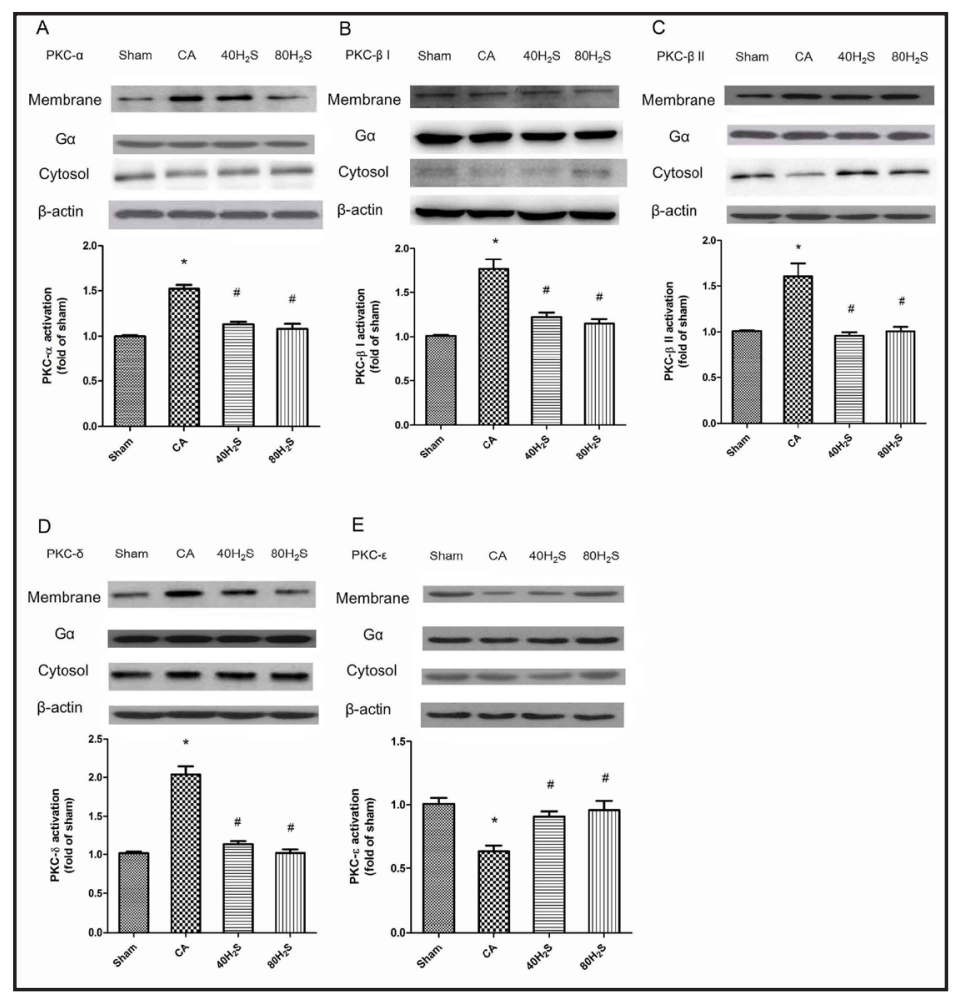

group in $80 \mathrm{H}_{2} \mathrm{~S}$ group) both in $40 \mathrm{H}_{2} \mathrm{~S}$ group and $80 \mathrm{H}_{2} \mathrm{~S}$ group $(P<0.05)$. These data indicated that inhalation of 40 p.p.m. or 80 p.p.m. $\mathrm{H}_{2} \mathrm{~S}$ inhibited the activation of PKC- $\alpha, \beta$ I, $\beta$ II and $\delta$, and promoted the activation of PKC- $\varepsilon$. However, no statistical differences were observed between the $40 \mathrm{H}_{2} \mathrm{~S}$ group and $80 \mathrm{H}_{2} \mathrm{~S}$ group.

\section{Hydrogen sulfide increases the expression of TJ proteins}

The expressions of TJ proteins including Claudin-5, Occludin, and ZO-1 were also measured at $24 \mathrm{~h}$ after ROSC using western blot assays. As shown in Fig. 5A-C, a significant decrease in Claudin-5 (0.64 \pm 0.17 -fold of Sham group, $P<0.05)$, Occludin $(0.66 \pm 0.07$-fold of Sham group, $P<0.05)$ or ZO-1 $(0.58 \pm 0.20$-fold of Sham group, $P<0.05)$ was observed in CA group when compared with Sham group. However, $\mathrm{H}_{2} \mathrm{~S}$ treatment reverted the expression of these TJ proteins. Compared with the CA group, the levels of Claudin-5 $(0.83 \pm 0.18$-fold of Sham group in $40 \mathrm{H}_{2} \mathrm{~S}$ group, $0.92 \pm 0.13$-fold of Sham group in $80 \mathrm{H}_{2} \mathrm{~S}$ group, respectively, $P<0.05)$, Occludin $\left(0.85 \pm 0.17\right.$-fold of Sham group in $40 \mathrm{H}_{2} \mathrm{~S}$ group, $0.97 \pm 0.18$-fold of Sham group in $80 \mathrm{H}_{2} \mathrm{~S}$ group, respectively, $\left.P<0.05\right)$ and ZO-1 $(0.89 \pm 0.12$-fold of Sham group in $40 \mathrm{H}_{2} \mathrm{~S}$ group, $0.88 \pm 0.22$-fold of Sham group in $80 \mathrm{H}_{2} \mathrm{~S}$ group, respectively, $P<0.05$ ) were significantly increased at $24 \mathrm{~h}$ after ROSC. There was no significant difference between the $40 \mathrm{H}_{2} \mathrm{~S}$ group and the $80 \mathrm{H}_{2} \mathrm{~S}$ group.

\section{Neurological deficit score and overall survival rate}

As shown in Fig. 6A, at $24 \mathrm{~h}$ after ROSC, neurological deficit scale in CA group [47 (44, 51)], $40 \mathrm{H}_{2} \mathrm{~S}$ group $[58(50,63)]$ and $80 \mathrm{H}_{2} \mathrm{~S}$ group $[60(53,63)]$ were significantly lower than in the Sham group $[79(78,80)]$ (all $P<0.05$ ). Compared with CA group, the NDS in $40 \mathrm{H}_{2} \mathrm{~S}$ group and $80 \mathrm{H}_{2} \mathrm{~S}$ group were significantly increased (both $P<0.05$ ). However, there was no significant difference between $40 \mathrm{H}_{2} \mathrm{~S}$ group and $80 \mathrm{H}_{2} \mathrm{~S}$ group. Furthermore, at $14 \mathrm{~d}$ after ROSC (Fig. 6B), neurological deficit scale in CA group [50 $(45,54)], 40 \mathrm{H}_{2} \mathrm{~S}$ group [65 (58, $68)]$ and $80 \mathrm{H}_{2} \mathrm{~S}$ group $[67(64,73)]$ were significantly lower than in the Sham group [80 $(79$, 80)] (all $P<0.05$ ). Compared with CA group, the NDS in $40 \mathrm{H}_{2} \mathrm{~S}$ group and $80 \mathrm{H}_{2} \mathrm{~S}$ group were significantly increased (both $P<0.05$ ). 
At the end of the experiment (14 d after ROSC), all rats in Sham group had survived (100\%, 5 of 5; Fig. 6C); while in the CA group, only 9 survived (45\%, 9 of 20). The survival rate in $40 \mathrm{H}_{2} \mathrm{~S}$ groups and $80 \mathrm{H}_{2} \mathrm{~S}$ group were $75 \%$ (15 of 20 ) or $80 \%$ (16 of 20 ) respectively, both significantly higher than the CA group $(P<0.05)$.

Fig. 5. Western blot analysis of Claudin-5 (A), Occludin (B), and ZO-1 (C) at $24 \mathrm{~h}$ after return of spontaneous circulation ( $\mathrm{n}=5$ in each group). Representative blots are shown and the bar charts provide protein expression quantification. Results are expressed as percentage of the Sham group. $\beta$-actin was used as internal control. $40 \mathrm{H}_{2} \mathrm{~S}, 40 \mathrm{H}_{2} \mathrm{~S}$ group; $80 \mathrm{H}_{2} \mathrm{~S}, 80 \mathrm{H}_{2} \mathrm{~S}$ group; CA, CA / CPR group. ${ }^{*} \mathrm{P}<0.05$ versus Sham group. ${ }^{*} \mathrm{P}<0.05$ versus CA group.

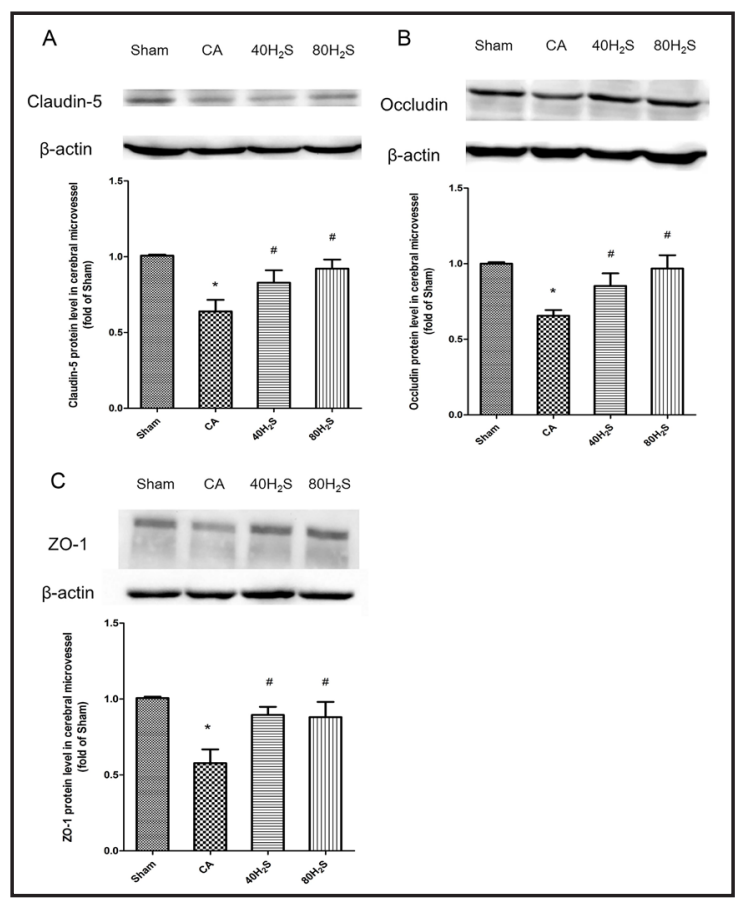

Fig. 6. Neurologic deficit scale and survival rate after return of spontaneous circulation. Neurologic deficit scale at $24 \mathrm{~h}$ (A) and $14 \mathrm{~d}$ (B) after return of spontaneous circulation. Scale 80 indicates a functionally normal; scale 0 represents brain death. Short transverse lines indicate median values. (C) Kaplan-Meier plot of survival rate $14 \mathrm{~d}$ after return of spontaneous circulation in Sham ( $n=5), C A(n=20), 40 \mathrm{H}_{2} \mathrm{~S}$ $(\mathrm{n}=20)$ and $80 \mathrm{H}_{2} \mathrm{~S}(\mathrm{n}=20)$ groups. (D) Representative histologic images of the hippocampus CA1 region, in sham $(n=5), C A(n=9)$, $40 \mathrm{H}_{2} \mathrm{~S}(\mathrm{n}=15)$ and $80 \mathrm{H}_{2} \mathrm{~S}(\mathrm{n}=16)$ groups, 14 days after cardiac arrest and resuscitation. All images were captured at $\times 400$ magnification.
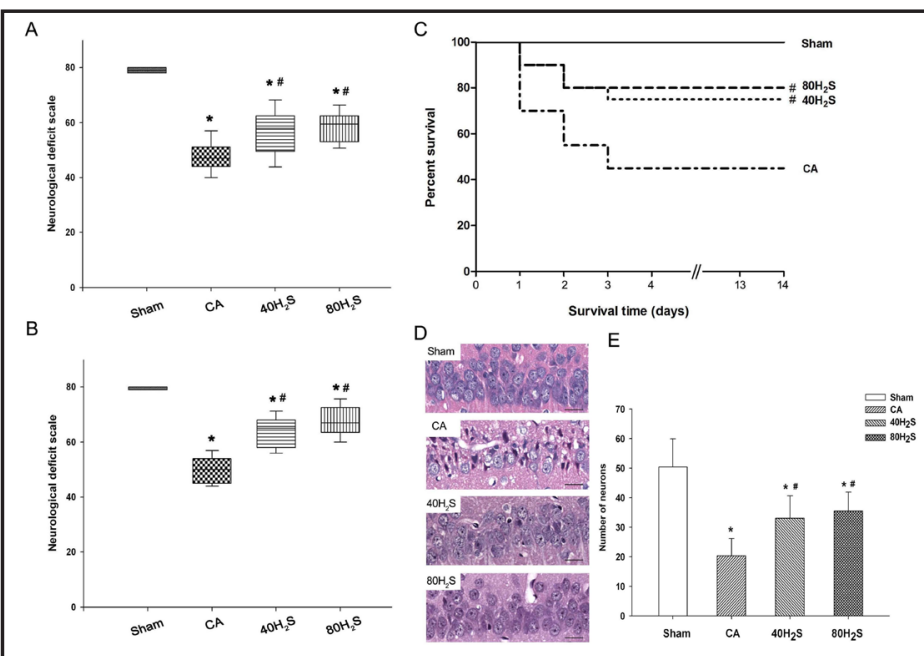

Scale bar indicates $100 \mu \mathrm{m}$. (E)

Number of viable neurons in the CA1 region of hippocampus belonging to different groups. $40 \mathrm{H}_{2} \mathrm{~S}, 40 \mathrm{H}_{2} \mathrm{~S}$ group; $80 \mathrm{H}_{2} \mathrm{~S}, 80 \mathrm{H}_{2} \mathrm{~S}$ group; CA, CA / CPR group. ${ }^{*} \mathrm{P}<0.05$ versus Sham group. ${ }^{\#} \mathrm{P}<0.05$ versus CA group. 


\section{Cellular Physiology Cell Physiol Biochem 2018;47:994-1006 and Biochemistry Publisned onIme: Ivay 30, $2018 \quad \begin{aligned} & \text { DOI: 10.1159/000490166 } 2018 \text { The Author(s). Published by S. Karger AG, Basel } \\ & \text { www.karger.com/cpb }\end{aligned}$}

Li et al.: $\mathrm{H}_{2} \mathrm{~S}$ Decreases BBB Damage via Regulating PKC and TJ in CA

\section{Neuronal Counts}

Fourteen days following ROSC, the numbers of viable neurons in the CA1 region in the CA group $(20 \pm 6), 40 \mathrm{H}_{2} \mathrm{~S}$ group $(33 \pm 8)$ and $80 \mathrm{H}_{2} \mathrm{~S}$ group $(36 \pm 6)$ were significantly lower than those of the Sham group, where neuronal death was rarely seen $(50 \pm 10$, both $P<$ 0.05 ) (Fig. 6E). Nuclear pyknosis, karyorrhexis, and vacuolization were seen in the $\mathrm{CA}, 40 \mathrm{H}_{2} \mathrm{~S}$ and $80 \mathrm{H}_{2} \mathrm{~S}$ groups (Fig. 6D). However, neuronal density and cell morphologies were better preserved in the $40 \mathrm{H}_{2} \mathrm{~S}$ and $80 \mathrm{H}_{2} \mathrm{~S}$ group, where the neuron counts were significantly higher than that of the CA group (both $P<0.05$ ). There was no significant difference between the $40 \mathrm{H}_{2} \mathrm{~S}$ group and the $80 \mathrm{H}_{2} \mathrm{~S}$ group.

\section{Discussion}

Cerebral ischemic/reperfusion injury (CIRI) caused by CA/CPR is a key factor in the prognosis of patients greatly impacting their quality of life [2]. Therefore, identification of strategies that can help in reduction of damage caused by CIRI and its prevention as well as efficient treatment is a major focus of clinical research.

In addition to nitric oxide and carbon monoxide, $\mathrm{H}_{2} \mathrm{~S}$ has been shown to have signal transduction properties in recent years [12]. Abe et al [26]. determined that endogenous $\mathrm{H}_{2} \mathrm{~S}$ may be a special kind of neuromodulator. In the central nervous system (CNS), endogenous $\mathrm{H}_{2} \mathrm{~S}$ is mainly generated through catalytic effects of 3-mercaptopyruvate sulfurtransferase and cystathionine- $\beta$-synthase on sulfur amino acids [13]. It is known that $\mathrm{H}_{2} \mathrm{~S}$ is not only involved in the neuroendocrine adjustment by the hypothalamus-pituitary-adrenal axis [27], but also affects cerebral blood flow by relaxing microvascular smooth muscles [28].

As an important endogenous gaseous mediator, $\mathrm{H}_{2} \mathrm{~S}$ plays an important role in CNS ischemic diseases. Various studies have confirmed that $\mathrm{H}_{2} \mathrm{~S}$ attenuates ischemic brain injury by mitigating oxidative stress, inhibiting cell apoptosis, opening K-ATP channels, relaxing blood vessels, and alleviating astrocytic activation [13, 14, 29]. Consistent with these previous findings, we found that $\mathrm{H}_{2} \mathrm{~S}$ improved neurological function and increased survival rate after $\mathrm{CA}$ and resuscitation in the present study. However, the therapeutic effect of $\mathrm{H}_{2} \mathrm{~S}$ on brain injury remains controversial. In an experimental model of middle cerebral artery occlusion in rats, $\mathrm{Qu}$ et al [30]. found that exogenous $\mathrm{H}_{2} \mathrm{~S}$ aggravated acute focal cerebral ischemic injury. This contradiction is attributed to the different dose of donor of $\mathrm{H}_{2} \mathrm{~S}$, which lower rather than higher concentration of exogenous $\mathrm{H}_{2} \mathrm{~S}$ might offer a protection against the neuronal injury [31, 32].

Vasogenic edema is caused by increased permeability of brain capillaries and increased fluid leakage after CIRI; therefore, brain water content can directly represent the severity of cerebral edema [33]. Evans Blue assay is the most popular method for evaluation of BBB-disruption in experimental brain disease studies. Evans blue binds to serum albumin immediately after injection into the blood. The EB-albumin complex has a net molecular weight of $\sim 68 \mathrm{kDa}$ which is impermeable across BBB in normal circumstances. In pathological condition when the integrity of the BBB is damaged and permeability is increased, EBalbumin complex leaks outward from blood microvascular endothelial cells (BMECs) gap into the brain tissue; therefore, Evans blue leakage can reflect the destruction of BBB [34]. The results of this study showed that brain water content and Evans blue leakage in brain tissue significantly increased at $24 \mathrm{~h}$ after ROSC, suggesting that CA caused significant damage to BBB and severe brain edema. After inhalation of 40 p.p.m. or 80 p.p.m. $\mathrm{H}_{2} \mathrm{~S}$ in the early stage after ROSC, brain water content was significantly reduced and Evans blue leakage was also significantly reduced. These data indicated that the protective effect of inhaled $\mathrm{H}_{2} \mathrm{~S}$ in rats after $\mathrm{CA}$ and resuscitation was associated with preservation of the integrity of $\mathrm{BBB}$, reducing BBB permeability, and alleviating cerebral edema.

Previous studies have confirmed that the activation of PKC is the major factor in CIRI [5, 8, 35-38]. As previously reported, hypoxia-induced BBB permeability changes occur via a 
PKC-dependent mechanism. Activation of PKC modulates BBB endothelial cell permeability changes in vitro and in vivo BBB models [39]. A study of Shao et al [7]. showed that PKC- $\beta$ and PKC- $\beta$ II in human BMECs were activated after exposure to high glucose in an in vitro BBB model, and the activated PKC inhibited the expression of Occludin and undermined the integrity of BBB. Similar result was confirmed by transfecting BMECs with siRNA targeting PKC- $\beta$, in which the activation of PKC- $\beta$ was impeded and the BBB damage was mitigated [35]. A recent study demonstrated that Go6983 decreased the phosphorylation levels of PKC $\delta$ and inhibited the release of MMP-9, which suggested that PKC- $\delta$ participated in PAR1mediated MMP-9 release from pericytes, which lead to BBB dysfunction [40].

However, the role of PKC- $\varepsilon$ is different from PKC isozymes mentioned above. Previous study have reported that IL- 25 which is produced by BCECs up-regulates the expression of claudin-5 and protects against inflammatory cytokine-induced excessive BBB collapse through a PKC- $\varepsilon$-dependent pathway [41]. Similarly, Lucke-Wold and colleges [42] found that bryostatin-1, a specific PKC modulator, increased ameliorated BBB breakdown through reducing toxic PKC- $\alpha$ levels and increasing the neuroprotective isozyme PKC- $\varepsilon$. Consistent with these previous findings, our data showed that the expressions of PKC- $\alpha$, PKC- $\beta$ I, PKC- $\beta$ II and PKC- $\delta$ in cerebral microvessels were significantly increased in the cell membrane which suggested the activation of these PKC isozymes after CA and resuscitation in this study. However, the activation of PKC- $\varepsilon$ was significantly inhibited after ROSC.

As a third essential gas molecule, several studies have confirmed that $\mathrm{H}_{2} \mathrm{~S}$ could regulate the activation and expression of PKC [18, 43-45]. Tiong et al [17]. found that the protective effect of $\mathrm{H}_{2} \mathrm{~S}$ against 6-OHDA-induced cell apoptosis and death was PKC- $\alpha$, $\varepsilon$-dependent. In another study, inhibition of PKC suppressed the $\mathrm{H}_{2} \mathrm{~S}$-elevated $\mathrm{Ca}^{2+}$ influx in SH-SY5Y cells [43]. Furthermore, it was confirmed that $\mathrm{H}_{2} \mathrm{~S}$ reduced myocardium infarct size by activating PKC- $\varepsilon$ and protecting the heart against ischemic/reperfusion injury [44]. In addition, Wei et al [45]. also found that exogenous $\mathrm{H}_{2} \mathrm{~S}$ activated PKC and down-regulated the expression of $\mathrm{AQP} 4$ in a local cerebral ischemia model. Similar to these investigations, the results in the present study indicated that the PKC- $\alpha$, PKC- $\beta$ I, PKC- $\beta$ II and PKC- $\delta$ were inhibited while the PKC- $\varepsilon$ was activated in cerebral microvessels after inhalation of 40 p.p.m. or 80 p.p.m. $\mathrm{H}_{2} \mathrm{~S}$. The present findings, in conjunction with these previously published data [17, 43-45], suggest that $\mathrm{PKC}$ is involved in the protective effect of $\mathrm{H}_{2} \mathrm{~S}$ against $\mathrm{CA}$ and resuscitation.

The TJ protein is mainly responsible for the restriction of the paracellular transport of molecules across the BBB [46]. In an attempt to clarify the mechanisms underlying the improved BBB permeability observed after $\mathrm{H}_{2} \mathrm{~S}$ inhalation, we investigated the changes of TJ proteins. We found that the expression of Claudin-5, Occludin, and ZO-1 were significantly decreased after ROSC. However, inhalation of $\mathrm{H}_{2} \mathrm{~S}$ increased the expression of Claudin-5, Occludin, and ZO-1. In addition to this results, we also observed a decrease in Evans Blue extravasation and less BBB damage with improvement in neurological function after inhalation of $\mathrm{H}_{2} \mathrm{~S}$. Furthermore, a significant improvement in the number of neurons in hippocampus and survival rate was also observed at 14 day after ROSC. These results showed that the increase in the $\mathrm{TJ}$ protein expression could be one of the mechanisms underlying the protective effect of $\mathrm{H}_{2} \mathrm{~S}$ against $\mathrm{BBB}$ disruption after $\mathrm{CA}$ and resuscitation.

Previous studies have indicated that activated PKC phosphorylates TJ proteins or regulates their expression [4-6, 47]. It has been shown that the activation of PKC- $\alpha$ disrupts the TJ and causes the disassembly of occluding junction [48]. Another study has shown that the damage of TJ following hypoxic / aglycemia was exacerbated by the over expression of PKC- $\beta$ II which led to the increase of the hyperpermeability of BMECs [6]. Furthermore, Qi et al [5]. demonstrated that PKC- $\delta$ specifically resulted in the dysregulation of TJ components. Inhibition of PKC- $\delta$ significantly reduced the accumulation of PKC- $\delta$ in BMECs and prevented the hypertension-induced TJ disruption associated with BBB breakdown. In this study, we demonstrated that regulation of PKC isozymes by $\mathrm{H}_{2} \mathrm{~S}$ correlated with TJ proteins and BBB permeability changes induced by $\mathrm{CA}$ and resuscitation. Inhalation of $\mathrm{H}_{2} \mathrm{~S}$ improved the neurological function and survival rate, decreased the expression of PKC- $\alpha$, PKC- $\beta$ I, PKC- $\beta$ II, PKC- $\delta$, and increased the expression of PKC- $\varepsilon$. Taken together, these results suggest that 
it is likely that the protective effect of $\mathrm{H}_{2} \mathrm{~S}$ against CA and resuscitation was via a PKC/TJdependent pathway to alleviate BBB leakage. The inhalation of $\mathrm{H}_{2} \mathrm{~S}$ in the early CA setting could be used to mitigate BBB disruption and improve neurologic function.

However, the mechanism by which PKC modulates TJ proteins is still poorly understood. One hypothesis is that PKC may directly regulate the structure and function of TJ proteins, and the other is that PKC may be indirectly altering the TJ proteins by activating a downstream intracellular signaling pathway that in turn directly affects the TJ proteins [40]. Further investigations on the colocalization and distributions of TJ protein after CA and resuscitation with or without $\mathrm{H}_{2} \mathrm{~S}$ inhalation will be needed.

It remains controversial whether the effect of $\mathrm{H}_{2} \mathrm{~S}$ is dose-dependent or not. Johansen et al [49]. confirmed that the protective effect of NaHS on myocardium against ischemic/ reperfusion injury protection was not concentration-dependent. While the study of Gheibi et al [50]. in which a MCAO model was applied, the authors found that intraperitoneal injection of NaHS alleviated brain edema and the protective effect was dose-dependent. The contradiction may be due to the differences in experimental models, $\mathrm{H}_{2} \mathrm{~S}$ donors, concentration of drugs, as well as the models and timings of administering drugs. In our setting, $\mathrm{H}_{2} \mathrm{~S}$ gas was delivered via inhalation, and we did not observe a significant difference in almost all data between two concentrations, suggesting that therapeutic effect of inhalation of $\mathrm{H}_{2} \mathrm{~S}$ may have already reached the ceiling effect at 40 p.p.m. in this model. Further more in our next study, we will investigate whether $\mathrm{H}_{2} \mathrm{~S}$ inhalation has a dose-dependent effect at lower concentration or not and make an effort to find out the optimum concentration of $\mathrm{H}_{2} \mathrm{~S}$ needed for more beneficial effects and less side effects.

In conclusion, 40 p.p.m or 80 p.p. $\mathrm{H}_{2} \mathrm{~S}$ inhalation significantly improved the integrity of $\mathrm{BBB}$, mitigated brain edema, and improved neurological outcome and survival in rats after $\mathrm{CA}$ and resuscitation. The beneficial effect of $\mathrm{H}_{2} \mathrm{~S}$ could be associated with regulating PKCs. Potentially, the mechanism may be that inhalation of $\mathrm{H}_{2} \mathrm{~S}$ inhibits the activation of PKC- $\alpha$, PKC- $\beta$ I, PKC- $\beta$ II and PKC- $\delta$, and promotes the activation of PKC- $\varepsilon$, following which, the expression of Claudin-5, Occludin, and ZO-1 are increased to preserve the integrity of the BBB.

\section{Acknowledgements}

This research is supported by the National Natural Science Foundation of China (grant number 81372026, 81000822). The funding organizations had no role in the study design; in the collection, analysis, and interpretation of data; in the writing of the report; and in the decision to submit the article for publication.

\section{Disclosure Statement}

The authors declare that there is no conflict of interests.

\section{References}

1 Mozaffarian D, Benjamin EJ, Go AS, Arnett DK, Blaha MJ, Cushman M, de Ferranti S, Després JP, Fullerton HJ, Howard VJ, Huffman MD, Judd SE, Kissela BM, Lackland DT, Lichtman JH, Lisabeth LD, Liu S, Mackey RH, Matchar DB, McGuire DK, Mohler ER 3rd, Moy CS, Muntner P, Mussolino ME, Nasir K, Neumar RW, Nichol G, Palaniappan L, Pandey DK, Reeves MJ, Rodriguez CJ, Sorlie PD, Stein J, TowFighi A, Turan TN, Virani SS, Willey JZ, Woo D, Yeh RW, Turner MB; American Heart Association Statistics Committee and Stroke Statistics Subcommittee: Heart disease and stroke statistics--2015 update: a report from the American Heart Association. Circulation 2005;131:e29-322. 


\section{Cellular Physiology Cell Physiol Biochem 2018;47:994-1006 and Biochemistry Publisned onIIne: IVlay 30, $2018 \quad \begin{aligned} & \text { DOI: 10.1159/000490166 } 2018 \text { The Author(s). Published by S. Karger AG, Basel } \\ & \text { www.karger.com/cpb }\end{aligned}$}

Li et al.: $\mathrm{H}_{2} \mathrm{~S}$ Decreases BBB Damage via Regulating PKC and TJ in CA

2 Gueugniaud PY, David JS, Chanzy E, Hubert H, Dubien PY, Mauriaucourt P, Bragança C, Billères X, ClotteauLambert MP, Fuster P, Thiercelin D, Debaty G, Ricard-Hibon A, Roux P, Espesson C, Querellou E, Ducros L, Ecollan P, Halbout L, Savary D, Guillaumée F, Maupoint R, Capelle P, Bracq C, Dreyfus P, Nouguier P, Gache A, Meurisse C, Boulanger B, Lae C, Metzger J, Raphael V, Beruben A, Wenzel V, Guinhouya C, Vilhelm C, Marret E: Vasopressin and epinephrine vs. epinephrine alone in cardiopulmonary resuscitation. N Engl J Med 2008;359: 21-30.

3 Miclescu A, Sharma HS, Martijn C, Wiklund L: Methylene blue protects the cortical blood-brain barrier against ischemia/reperfusion-induced disruptions. Crit Care Med 2010;38:2199-2206.

-4 Eckert JJ, McCallum A, Mears A, Rumsby MG, Cameron IT, Fleming TP: PKC signalling regulates tight junction membrane assembly in the pre-implantation mouse embryo. Reproduction 2004;127:653-667.

-5 Qi X, Inagaki K, Sobel RA, Mochly-Rosen D: Sustained pharmacological inhibition of deltaPKC protects against hypertensive encephalopathy through prevention of blood-brain barrier breakdown in rats. J Clin Invest 2008;118:173-182.

6 Kim YA, Park SL, Kim MY, Lee SH, Baik EJ, Moon CH, Jung YS: Role of pkcbetaii and pkcdelta in blood-brain barrier permeability during aglycemic hypoxia. Neurosci Lett 2010;468:254-258.

7 Shao B, Bayraktutan U: Hyperglycaemia promotes cerebral barrier dysfunction through activation of protein kinase C-beta. Diabetes Obes Metab 2013;15:993-999.

8 Suzuki T, Elias BC, Seth A, Shen L, Turner JR, Giorgianni F, Desiderio D, Guntaka R, Rao R: PKC eta regulates occludin phosphorylation and epithelial tight junction integrity. Proc Natl Acad Sci U S A 2009;106: 61-66.

-9 Rosse C, Linch M, Kermorgant S, Cameron AJ, Boeckeler K, Parker PJ: PKC and the control of localized signal dynamics. Nat Rev Mol Cell Biol 2010;11:103-112.

10 Willis CL, Meske DS, Davis TP: Protein kinase c activation modulates reversible increase in cortical blood-brain barrier permeability and tight junction protein expression during hypoxia and posthypoxic reoxygenation. J Cereb Blood Flow Metab 2010;30:1847-1859.

11 Bright R, Mochly-Rosen D: The role of protein kinase $\mathrm{c}$ in cerebral ischemic and reperfusion injury. Stroke 2005;36:2781-2790.

12 Li L, Rose P, Moore PK: Hydrogen sulfide and cell signaling. Annu Rev Pharmacol Toxicol 2011;51:169-187.

13 Ma S, Zhong D, Ma P, Li G, Hua W, Sun Y, Liu N, Zhang L, Zhang W. Exogenous Hydrogen Sulfide Ameliorates Diabetes-Associated Cognitive Decline by Regulating the Mitochondria-Mediated Apoptotic Pathway and IL-23/IL-17 Expression in db/db Mice. Cell Physiol Biochem. 2017;41:1838-1850.

14 Kimura H: Hydrogen sulfide: its production and functions. Exp Physiol 2011;96:833-835.

15 Geng Y, Li E, Mu Q, Zhang Y, Wei X, Li H, Cheng L, Zhang B: Hydrogen sulfide inhalation decreases early blood-brain barrier permeability and brain edema induced by cardiac arrest and resuscitation. J Cereb Blood Flow Metab 2015;35:494-500.

16 Wei X, Duan L, Bai L, Tian M, Li W, Zhang B: Effects of exogenous hydrogen sulfide on brain metabolism and early neurological function in rabbits after cardiac arrest. Intensive Care Med 2012;38:1877-1885.

17 Tiong CX, Lu M, Bian JS: Protective effect of hydrogen sulphide against 6-ohda-induced cell injury in shsy5y cells involves pkc/pi3k/akt pathway. Br J Pharmacol 2010;161:467-480.

18 Kilkenny C, Browne W, Cuthill IC, Emerson M, Altman DG;NC3Rs Reporting Guidelines Working Group: Animal research: reporting in vivo experiments: the ARRIVE guidelines. Br J Pharmacol 2010;160:15771579.

19 McGrath JC, Drummond GB, McLachlan EM, Kilkenny C, Wainwright CL: Guidelines for reporting experiments involving animals: the ARRIVE guidelines. Br J Pharmacol 2010;160:1573-1576.

20 Kwon WY, Suh GJ, Kim KS, Lee HJ, Jeong KY, Kwak YH, Kim K: Niacin suppresses the mitogen-activated protein kinase pathway and attenuates brain injury after cardiac arrest in rats. Crit Care Med 2013;41:e223-e232.

-21 Dzialowski I, Weber J, Doerfler A, Forsting M, von Kummer R: Brain tissue water uptake after middle cerebral artery occlusion assessed with CT. J Neuroimaging 2004;14:42-48.

22 Witt KA, Mark KS, Huber J, Davis TP: Hypoxia-inducible factor and nuclear factor kappa-b activation in blood-brain barrier endothelium under hypoxic/reoxygenation stress. J Neurochem 2005;92:203-214.

23 Jia X, Koenig MA, Shin HC, Zhen G, Pardo CA, Hanley DF, Thakor NV, Geocadin RG: Improving neurological outcomes post-cardiac arrest in a rat model: immediate hypothermia and quantitative EEG monitoring. Resuscitation 2008;76: 431-442. 


\section{Cellular Physiology Cell Physiol Biochem 2018;47:994-1006 \begin{tabular}{ll|l} 
DOI: 10.1159/000490166 & $\begin{array}{l}\text { O 2018 The Author(s). Published by S. Karger AG, Basel } \\
\text { www.karger.com/cpb }\end{array}$ \\
\hline
\end{tabular}}

Li et al.: $\mathrm{H}_{2} \mathrm{~S}$ Decreases BBB Damage via Regulating PKC and TJ in CA

24 Paxinos G, Watson C (eds). The Rat Brain in Stereotaxic Coordinates. 5th edn, Elsevier Academic Press: Amsterdam, 2005.

25 Xiong WX, Zhou GX, Wang B, Xue ZG, Wang L, Sun HC, Ge SJ. Impaired spatial learning and memory after sevoflurane-nitrous oxide anesthesia in aged rats is associated with down-regulated cAMP/CREB signaling. PLoS One. 2013;8:e79408.

-26 Abe K, Kimura K: The possible role of hydrogen sulfide as an endogenous neuromodulator. J Neurosci 1996;16:1066-1071.

-27 Dello Russo C, Tringali G, Ragazzoni E, Maggiano N, Menini E, Vairano M, Preziosi P, Navarra P: Evidence that hydrogen sulphide can modulate hypothalamo-pituitary-adrenal axis function: in vitro and in vivo studies in the rat. J of Neuroendocrinol 2000;12:225-233.

28 Zhao W, Zhang J, Lu Y, Wang R: The vasorelaxant effect of H2S as a novel endogenous gaseous KATP channel opener. ЕMBO J 2001;20:6008-6016.

-29 Liu Y, Liao S, Quan H, Lin Y, Li J, Yang Q. Involvement of microRNA-135a-5p in the Protective Effects of Hydrogen Sulfide Against Parkinson's Disease. Cell Physiol Biochem 2016;40:18-26.

-30 Qu K, Chen CP, Halliwell B, Moore PK, Wong PT: Hydrogen sulfide is a mediator of cerebral ischemic damage. Stroke 2006;37:889-893.

-31 Ren C, Du A, Li D, Sui J, Mayhan WG, Zhao H: Dynamic change of hydrogen sulfide during global cerebral ischemia-reperfusion and its effect in rats. Brain Res 2010;1345:197-205.

-32 Li GF, Luo HK, Li LF, Zhang QZ, Xie LJ, Jiang H, Li LP, Hao N, Wang WW, Zhang JX: Dual effects of hydrogen sulphide on focal cerebral ischaemic injury via modulation of oxidative stress-induced apoptosis. Clin Exp Pharmacol Physiol 2012;39:765-771.

-33 Obermeier B, Daneman R, Ransohoff RM: Development, maintenance and disruption of the blood-brain barrier. Nat Med 2013;19:1584-1596.

-34 Hayasaka N, Nagai N, Kawao N, Niwa A, Yoshioka Y, Mori Y, Shigeta H, Kashiwagi N, Miyazawa M, Satou T, Higashino H, Matsuo O, Murakami T: In vivo Diagnostic Imaging Using Micro-CT: Sequential and Comparative Evaluation of Rodent Models for Hepatic/Brain Ischemia and Stroke. PLoS One 2012;7:e32342.

- 35 Srivastava K, Shao B, Bayraktutan U: PKC-beta exacerbates in vitro brain barrier damage in hyperglycemic settings via regulation of RhoA/Rho-kinase/MLC2 pathway. J Cereb Blood Flow Metab 2013;33:1928-1936.

-36 Lee BK, Yoon JS, Lee MG, Jung YS. Protein kinase C-beta mediates neuronal activation of $\mathrm{Na}(+) / \mathrm{H}(+)$ exchanger-1 during glutamate excitotoxicity. Cell Signal 2014;26:697-704.

37 Lin HW, Defazio RA, Della-Morte D, Thompson JW, Narayanan SV, Raval AP, Saul I, Dave KR, PerezPinzon MA: Derangements of post-ischemic cerebral blood flow by protein kinase c delta. Neuroscience 2010;171:566-576.

38 Sun X, Budas G R, Xu L, Barreto GE, Mochly-Rosen D, Giffard RG: Selective activation of protein kinase c in mitochondria is neuroprotective in vitro and reduces focal ischemic brain injury in mice. J Neurosci Res 2013;91:799-807.

-39 Fleegal MA, Hom S, Borg LK, Davis TP: Activation of PKC modulates blood-brain barrier endothelial cell permeability changes induced by hypoxia and posthypoxic reoxygenation. Am J Physiol Heart Circ Physiol 2005;289:H2012-H2019.

40 Machida T, Dohgu S, Takata F, Matsumoto J, Kimura I, Koga M, Nakamoto K, Yamauchi A, Kataoka Y: Role of thrombin-PAR1-PKC $\theta / \delta$ axis in brain pericytes in thrombin-induced MMP-9 production and blood-brain barrier dysfunction in vitro. Neuroscience 2017;350:146-157.

41 Sonobe Y, Takeuchi H, Kataoka K, Li H, Jin S, Mimuro M, Hashizume Y, Sano Y, Kanda T, Mizuno T, Suzumura A: Interleukin-25 expressed by brain capillary endothelial cells maintains blood-brain barrier function in a protein kinase Cepsilon-dependent manner. J Biol Chem 2009;284:31834-31842.

42 Lucke-Wold BP, Logsdon AF, Smith KE, Turner RC, Alkon DL, Tan Z, Naser ZJ, Knotts CM, Huber JD, Rosen CL: Bryostatin-1 restores blood brain barrier integrity following blast-induced traumatic brain injury. Mol Neurobiol 2015;52:1119-1134.

43 Yong QC, Choo CH, Tan BH, Low CM, Bian JS: Effect of hydrogen sulfide on intracellular calcium homeostasis in neuronal cells. Neurochem Int 2010;56:508-515.

-44 Yong QC, Lee SW, Foo CS, Neo KL, Chen X, Bian JS: Endogenous hydrogen sulphide mediates the cardioprotection induced by ischemic postconditioning. Am J Physiol Heart Circ Physiol 2008;295:H1330-H1340. 


\section{Cellular Physiology Cell Physiol Biochem 2018;47:994-1006 \begin{tabular}{l|l} 
DOI: 10.1159/000490166 & $\begin{array}{l}\text { O 2018 The Author(s). Published by S. Karger AG, Basel } \\
\text { www.karger.com/cpb }\end{array}$ \\
\hline
\end{tabular} \\ Li et al.: $\mathrm{H}_{2} \mathrm{~S}$ Decreases BBB Damage via Regulating PKC and TJ in CA}

45 Wei X, Zhang B, Cheng L, Chi M, Deng L, Pan H, Yao X, Wang G: Hydrogen sulfide induces neuroprotection against experimental stroke in rats by down-regulation of AQP4 via activating PKC. Brain Res, 2015;1622: 292-299.

46 Carvey PM1, Hendey B, Monahan AJ: The blood-brain barrier in neurodegenerative disease: a rhetorical perspective. J Neurochem 2009;111:291-314.

-47 Rigor RR, Beard RS Jr, Litovka OP, Yuan SY: Interleukin-1 $\beta$-induced barrier dysfunction is signaled through PKC- $\theta$ in human brain microvascular endothelium. Am J Physiol Cell Physiol 2012;302:C1513-C1522.

-48 Smith JM, Dornish M, Wood EJ: Involvement of protein kinase C in chitosan glutamate-mediated tight junction disruption. Biomaterials 2005;26:3269-3276.

49 Johansen D,Ytrehus K, Baxter GF: Exogenous hydrogen sulfide (H2S) protects against regional myocardial ischemia-reperfusion injury-Evidence for a role of K ATP channels. Basic Res Cardiol 2006;101:53-60.

50 Gheibi S, Aboutaleb N, Khaksari M, Kalalian-Moghaddam H, Vakili A, Asadi Y, Mehrjerdi FZ, Gheibi A: Hydrogen sulfide protects the brain against ischemic reperfusion injury in a transient model of focal cerebral ischemia. J Mol Neurosci 2014;54:264-270. 